ISSN 1392-3196 / e-ISSN 2335-8947

Zemdirbyste-Agriculture, vol. 108, No. 1 (2021), p. 11-18

DOI 10.13080/z-a.2021.108.002

\title{
The impact of tillage practices on the distribution of humified organic carbon in a clay loam
}

\author{
Inga LIAUDANSKIENE ${ }^{1}$, Tomas ZUKAITIS ${ }^{1}$, Aleksandras VELYKIS ${ }^{2}$, \\ Antanas SATKUS ${ }^{2}$, Irmantas PARASOTAS ${ }^{1}$ \\ ${ }^{1}$ Lithuanian Research Centre for Agriculture and Forestry \\ Instituto 1, Akademija, Kèdainiai distr., Lithuania \\ E-mail: inga.liaudanskiene@lammc.lt \\ ${ }^{2}$ Lithuanian Research Centre for Agriculture and Forestry \\ Karpių 1, Joniškèlis, Pasvalys distr., Lithuania
}

\begin{abstract}
A field experiment was carried out at the Joniškèlis Experimental Station of Lithuanian Research Centre for Agriculture and Forestry in 2016-2018 to ascertain the effects of reduced tillage and the combinations of reduced tillage with soil improvement practices on soil organic carbon (SOC) and quantity and quality of humus in a clay loam. The following tillage systems were investigated: 1) deep ploughing (DP) at $21-23 \mathrm{~cm}$ depth (control), 2) shallow ploughing at 15-17 cm depth (SP), 3) ploughless tillage (at 10-12 cm depth) (PT), 4) ploughless tillage and aftereffect of lime sludge last incorporated in 2014 (PT + aLS), 5) ploughless tillage with cover crops for green manure $(\mathrm{PT}+\mathrm{GM})$ and 6$)$ no-tillage with cover crop for winter mulch $(\mathrm{NT}+\mathrm{WM})$. The reduction of tillage intensity increased the contents of SOC and $\mathrm{C}$ in humic substances (HS) in the upper $(0-10 \mathrm{~cm})$ soil layer. The incorporation of organic sources in the form of green manure and winter mulch promoted microbiological activity and the mineralization of the soil organic matter (SOM) already present in it. However, the SOC and total nitrogen $\left(\mathrm{N}_{\text {tof }}\right)$ content did not increase in proportion to the fresh organic matter incorporated. The tillage systems applied had influence on the changes in the humus fractional composition. The increased content of plant residues under $\mathrm{PT}+\mathrm{GM}$ and NT + WM treatments resulted in higher amounts of mobile HS in the upper soil layer, meanwhile the PT + aLS treatment increased the amount of agronomically most valuable Ca-bound HS. Higher amounts of HS bound with clay minerals were found under PT + aLS treatment, as calcium (Ca) is an important factor for SOC sequestration in a clay. The humification degree increased in 0-30 cm soil layer under all reduced tillage systems investigated compared to the DP (control). The use of soil improvers had a more significant effect than just reduction of tillage. However, due to the complexity of SOM a clear relationship between SOM qualitative characteristics and tillage practices applied was not identified.
\end{abstract}

Key words: fulvic acids, humic acids, humification degree, humin, soil organic carbon

\section{Introduction}

Soils are an essential and non-renewable resource hosting goods and services vital to ecosystems and human life. One of the basic guidelines for sustainable soil management is to enhance soil organic matter (SOM) content. In addition, maintenance and enhancement of soil are closely related to the nine guidelines of Sustainable Development Goals, the implementation of which is closely linked to the functions of organic matter in the soil (FAO, 2017). At the United Nations Conference on Sustainable Development (Rio+20 Meeting) in 2012, it was shown that extensive land and soil degradation still occurs all over the world and fertile soil resources are still rapidly depleted (Keesstra et al., 2016). The quality, productivity and sustainability of soil and other terrestrial ecosystem renewable components (vegetation, fauna and microbiota) is determined by the ability to accumulate SOM. SOM is a chemically complex, heterogeneous mixture of thousands of biotically and abiotically processed molecules (Ohno et al., 2019), which is a critical component of the soil-plant ecosystem and plays a key role in maintaining the productivity of soil, providing energy and substrate for the biological activity and modifying the chemical and physical soil properties that ensure the maintenance of soil quality and the sustainability of agroecosystems (Silva et al., 2016).

Humic substances are the result of chemical and biochemical transformations of plant and animal biomasses and synthetic activity of soil microbiota, representing the highest and most stable percentage of total soil organic carbon (SOC), and have irregular structure, varying composition, high degree of polymerization, high surface reactivity and high molecular weight, acting

Please use the following format when citing the article:

Liaudanskiene I., Zukaitis T., Velykis A., Satkus A., Parasotas I. 2021. The impact of tillage practices on the distribution of humified organic carbon in a clay loam. Zemdirbyste-Agriculture, 108 (1): 11-18. DOI 10.13080/z-a.2021.108.002 
as a nutrient reservoir and contributing to chemical stabilization of soil micro-aggregates (Nebbioso et al., 2015; Silva et al., 2016; Weber et al., 2018). Management practices can change soil conditions that influence the process of humification. Soil acidity $(\mathrm{pH})$, content and composition of exchangeable cations, content of humusforming agents - these soil properties determine the rate and direction of humification, but there is no consistent opinion on the influence of tillage on humic substances (Ovchinnikova, 2009). Although humic substances are relatively stable and resistant to decomposition, the longterm intensive tillage promotes the degradation of SOM (Lapa et al., 2011).

Recently, the Lithuanian natural bio-climatic conditions have been causing changes in the factors affecting soil microorganisms, which determines the quantity and diversity of humus compounds. Intensive crop production technologies result in the largest part of phytomass produced by crops being removed from fields as marketable production, and only belowground residues are left in the soil. The assessment and characterization of SOM play an important role in predicting the ecological stability and fertility of soils. The challenge is to maintain the amount of organic matter in the soil and to identify the means to improve its quality. It is known that the addition of lime sludge, a by-product from the purification-flocculation process of colloid matter from the liquor extracted from sugar beet, reduces the acidity of the soil, helps to maintain the structure of soil aggregates, but there are only few publications on lime sludge as a stabilizing agent for labile soil organic compounds.

The main task of this study was to verify the hypothesis that replacement of conventional intensive soil tillage by long-term less-intensive reduced tillage and the combinations of reduced tillage with soil improvement practices will maintain or increase the soil organic carbon as well the quantity and quality of humic substances in a clay loam.

\section{Materials and methods}

Experimental site. A field experiment was carried out in 2016-2018 at the Joniškelis Experimental Station of Lithuanian Research Centre for Agriculture and Forestry, located in the northern part of Central Lithuanian Lowland $\left(56^{\circ} 21^{\prime} \mathrm{N}, 24^{\circ} 10^{\prime} \mathrm{E}\right)$, in the long-term experiment, established in 2006. The objective of the research was to evaluate the long-term effects of reduced tillage on soil organic carbon (SOC) and humus composition in different soil layers. The soil of the experimental site is Endocalcari-Endohypogleyic Cambisol (Siltic, Drainic) (WRB, 2014). Before the experiment, the characteristics of the plough layer $(0-30 \mathrm{~cm})$ were as follows: texture - clay loam ( $22.7 \%$ sand, $50.3 \%$ silt, $27 \%$ clay), acidity $(\mathrm{pH})-6.6$, humus content $-2.35 \%$, total nitrogen $\left(\mathrm{N}_{\text {to }}\right)$ $-0.156 \%$, total phosphorus $(\mathrm{P})-0.054 \%$, plant available phosphorus $\left(\mathrm{P}_{2} \mathrm{O}_{5}\right)-137 \mathrm{mg} \mathrm{kg}^{-1}$ and potassium $\left(\mathrm{K}_{2} \mathrm{O}\right)$ $-309 \mathrm{mg} \mathrm{kg}^{-1}$. The investigation of the impact of reduced tillage and its combinations with soil improvement practices on SOC and humus composition involved the following treatments: 1) deep ploughing (DP) at 21$23 \mathrm{~cm}$ depth (control), 2) shallow ploughing at $15-17 \mathrm{~cm}$ depth (SP), 3) ploughless tillage at 10-12 cm depth (PT), 4) ploughless tillage at $10-12 \mathrm{~cm}$ depth and aftereffect of lime sludge last incorporated in 2014 (PT + aLS), 5) ploughless tillage at $10-12 \mathrm{~cm}$ depth with cover crops for green manure $(\mathrm{PT}+\mathrm{GM})$ and 6$)$ no-tillage with cover crop for winter mulch (NT + WM). The field trial was laid out in a randomized single row design with four replicates. Each tilled sub-plot size was $16 \times 5=80 \mathrm{~m}^{2}$, of which $13 \times 2.3=29.9 \mathrm{~m}^{2}$ was harvested.

The experiment was conducted in the crop rotation: field pea (Pisum sativum L. (Partim) $\rightarrow$ winter wheat (Triticum aestivum L.) $\rightarrow$ spring oilseed rape (Brasica napus L.) $\rightarrow$ spring barley (Hordeum vulgare L.). Cover crops were grown as follows: before field pea - a mixture of white mustard (Sinapis alba L.) and oilseed radish (Raphanus sativus L.), before spring oilseed rape - a mixture of field pea, common vetch (Vicia sativa L.) and blue lupine (Lupinus angustifolius L.), before spring barley - oat (Avena sativa L.). The straw of the pre-crop was chopped during harvesting and incorporated into the soil at 6-8 cm depth; post-harvest cover crops were sown after stubble cultivation. Lime sludge $\left(7.0 \mathrm{t} \mathrm{ha}^{-1}\right)$ was incorporated three times for spring crops during the first stage of the experiment (2007-2010) and once for spring barley during the second stage of the experiment (20112014) to improve soil physical properties and structure, but the soil acidity in the plough layer reached the level of neutral and slightly alkaline soils $(\mathrm{pH}=7.2)$, which is the upper value of the optimum $\mathrm{pH}$ range for agricultural crops (Velykis, Satkus, 2018), and only the residual effect of lime sludge was investigated in this experiment. Cover crop for winter mulch was left intact in the autumn, and its frost-killed residues covered the soil. All rotational crops were fertilized with $\mathrm{P}_{90} \mathrm{~K}_{60}$ before sowing.

Soil sampling and analysis methods. Soil samples were collected annually after the main crop harvest, 8 subsamples per plot were taken randomly with a steel auger. Each soil sample core was separated into 0-10, 10-20 and $20-30 \mathrm{~cm}$ depth and combined across sub-samples by depth for each plot. The soil samples were air-dried, visible roots and plant residues were removed manually. Then the samples were crushed and sieved through a 2-mm sieve and homogeneously mixed. Soil $\mathrm{pH}$ was determined by the potentiometric method in $1 \mathrm{M} \mathrm{KCl}$ (soil-to-solution ratio 1:2.5). The $\mathrm{N}_{\text {tot }}$ content was determined using spectrophotometric measure procedure at a wavelength of $655 \mathrm{~nm}$ aftermineralization with sulphuric acid $\left(\mathrm{H}_{2} \mathrm{SO}_{4}\right)$. For the analysis of SOC and humic substances (HS), an aliquot of the samples was passed through a $0.25-\mathrm{mm}$ sieve. The content of SOC was determined according to the Nikitinmodified (Nikitin, 1999) Tyurin method. The group and fractional composition of soil humus were determined by the Ponomareva and Plotnikova (1980) version of Tyurin method according to the scheme presented in Figure. This procedure allows calculating the content of free, calcium (Ca) and clay mineral-bound fractions of humic (HA) and fulvic (FA) acids as well as humic-to-fulvic acids ratio (HA:FA). SOC content of isolated HS was determined via the modified Turin's method (Nikitin, 1999), which consists of dichromate digestion at $160^{\circ} \mathrm{C}$ temperature for $30 \mathrm{~min}$ and spectrophotometric measurement procedure at a wavelength of $590 \mathrm{~nm}$ using glucose as a standard.

The residual precipitate remaining after the $2^{\text {nd }}$ extraction procedure corresponded to the humin (fraction of humic substances not soluble in water at any $\mathrm{pH}$, most resistant to decomposition), which was dried in a laboratory oven at $45^{\circ} \mathrm{C}$ temperature, and the SOC content in humin fraction was determined by the method described above for SOC.

The humification degree (HD) according to Orlov et al. (2004) is understood as the relative proportion of HA carbon content in the total amount of SOC and was expressed as a percentage:

$$
\mathrm{HD}, \%=\frac{\mathrm{HA}}{\mathrm{SOC}} \times 100 \text {, }
$$

where $\mathrm{HA}$ is humic acids $\mathrm{C}$ content, $\mathrm{g} \mathrm{kg}^{-1}$; $\mathrm{SOC}$ - soil organic carbon content, $\mathrm{g} \mathrm{kg}^{-1}$. 


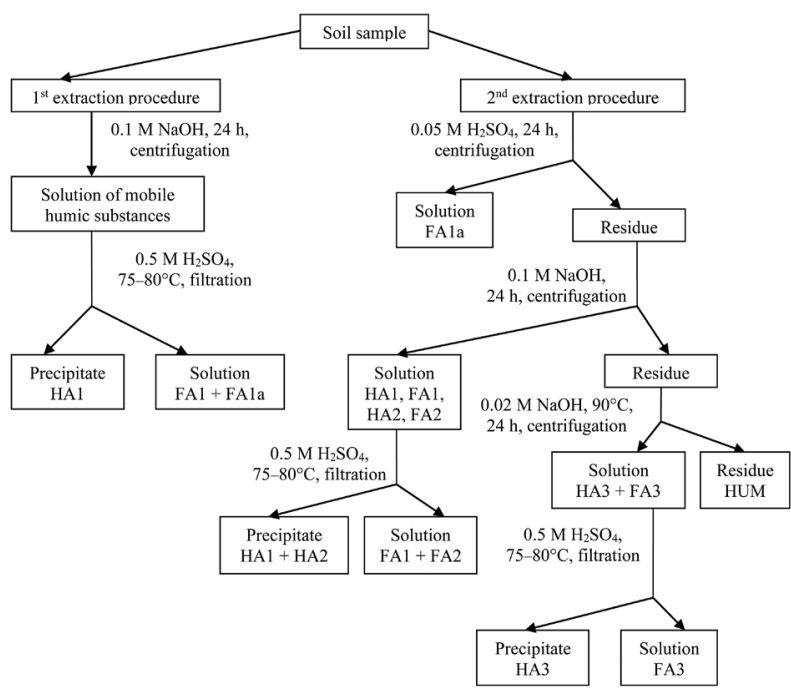

Figure. The scheme of humus fractionation (according to Ponomareva and Plotnikova, 1980)

The aggressiveness of HS is characterized by the relative proportion of the most aggressive FAla fraction $\mathrm{C}$ content in total extractable humified $\mathrm{C}$ content according to formula:

Aggressiveness, $\%=\frac{\mathrm{FA} 1 \mathrm{a}}{\mathrm{HA}+\mathrm{FA}} \times 100$,

where FA1 a is $\mathrm{C}$ content of the most aggressive FAla fraction, $\mathrm{g} \mathrm{kg}^{-1}$; $\mathrm{HA}$ - humic acids $\mathrm{C}$ content, $\mathrm{g} \mathrm{kg}^{-1}$; $\mathrm{FA}$ - fulvic acids $\mathrm{C}$ content, $\mathrm{g} \mathrm{kg}^{-1}$.

The coefficient of humus mobility was calculated as a ratio between mobile and $\mathrm{Ca}$-bound $\mathrm{HA}$ and FA carbon content according to formula:

Mobility $=\frac{\text { HA1 }+ \text { FA1 }}{\text { HA2 }+ \text { FA2 }}$

where HA1 and FA1 - C content of mobile humic and fulvic acids, $\mathrm{g} \mathrm{kg}^{-1}$; HA2 and FA2 - $\mathrm{C}$ content of Ca-bound humic and fulvic acids, $\mathrm{g} \mathrm{kg}^{-1}$.

Statistical analysis was done using the software SAS Enterprise, version 7.1 (SAS Institute Inc., USA). All results of SOC, $\mathrm{N}_{\text {tot }}$ and humus fractional composition are the means of three field replicates. Differences among the experimental treatments were tested by the analysis of variance (one-way $A N O V A$ ). The means were compared by using least significant differences (LSD) calculated at the 0.05 probability level (Fisher's LSD test).

\section{Results and discussion}

Soil $\mathrm{pH}$ is often considered as a dominant factor regulating direct and indirect processes that take place in the soil, including organic matter turnover (Kemmitt et al., 2006). The data presented in Table 1 shows that the reduction of tillage intensity did not affect the soil $\mathrm{pH}$. However, reduced tillage combined with additional measures increased soil $\mathrm{pH}$, but only aftereffect of lime sludge $(\mathrm{PT}+\mathrm{aLS}) \mathrm{had}$ a significant influence in all soil layers compared with DP (control) treatment. The use of cover crops for green manure $(\mathrm{PT}+\mathrm{GM})$ and for winter mulch $(\mathrm{NT}+\mathrm{WM})$ tended to increase the soil $\mathrm{pH}$, but a significant increase in $\mathrm{pH}$ was found only in $20-30 \mathrm{~cm}$ soil layer.

Many decades of research have shown that SOM, whose main element is SOC, plays an important role in a wide range of soil properties and processes. The cessation of ploughing or reduction of tillage intensity generally reduces disturbance and provides better protection of SOC against decomposition (Laganiere et al., 2010), but the changes in the total SOC content become evident after
Table 1. Soil acidity ( $\mathrm{pH})$, soil organic carbon (SOC) and total nitrogen $\left(\mathrm{N}_{\text {tot }}\right)$ content and $\mathrm{C}$-to- $\mathrm{N}$ ratio $(\mathrm{C}: \mathrm{N})$ in different soil layers (2016-2018)

\begin{tabular}{|c|c|c|c|c|}
\hline \multirow{2}{*}{$\begin{array}{l}\text { Tillage } \\
\text { system }\end{array}$} & \multirow{2}{*}{$\mathrm{pH}$} & SOC & $\mathrm{N}_{\text {tot }}$ & \multirow{2}{*}{$\mathrm{C}: \mathrm{N}$} \\
\hline & & \multicolumn{2}{|c|}{$\mathrm{g} \mathrm{kg}^{-1}$ soil } & \\
\hline \multicolumn{5}{|c|}{$0-10 \mathrm{~cm}$ layer } \\
\hline DP & 6.07 & 14.11 & .466 & 9.712 \\
\hline $\begin{array}{l}\text { SP } \\
\text { PT }\end{array}$ & $\begin{array}{l}6.09 \\
6.05\end{array}$ & $\begin{array}{l}14.72 \\
15.09^{*}\end{array}$ & .447 & $\begin{array}{l}10.17 \\
9.630\end{array}$ \\
\hline $\mathrm{PT}+\mathrm{aLS}$ & $7.04 *$ & $15.57 *$ & .008 & $\begin{array}{l}9.030 \\
9.688\end{array}$ \\
\hline $\begin{array}{l}\mathrm{PT}+\mathrm{GM} \\
\mathrm{NT}+\mathrm{WM}\end{array}$ & $\begin{array}{l}6.29 \\
6.22\end{array}$ & $\begin{array}{l}15.16^{*} \\
14.41\end{array}$ & $\begin{array}{l}1.485 \\
1.477\end{array}$ & $\begin{array}{l}10.21 \\
9765\end{array}$ \\
\hline $\mathrm{LSD}_{05}$ & 0.284 & 0.082 & 0.1773 & 1.135 \\
\hline \multicolumn{5}{|c|}{$10-20 \mathrm{~cm}$ layer } \\
\hline DP & 6.27 & 13.58 & 1.423 & 9.600 \\
\hline $\begin{array}{l}\text { SP } \\
\text { PT }\end{array}$ & $\begin{array}{l}6.25 \\
6.26\end{array}$ & $13.04 *$ & $\begin{array}{l}1.259^{*} \\
1.346\end{array}$ & $\begin{array}{l}10.38 \\
9.183\end{array}$ \\
\hline $\mathrm{PT}+\mathrm{aLS}$ & $7.11 *$ & $12.02 *$ & $1.247 *$ & 9.641 \\
\hline $\begin{array}{l}\mathrm{PT}+\mathrm{GM} \\
\mathrm{NT}+\mathrm{WM}\end{array}$ & $\begin{array}{l}6.42 \\
6.34\end{array}$ & $\begin{array}{l}11.52 * \\
11.65 *\end{array}$ & $1.217 *$ & $\begin{array}{l}9.464 \\
9.575\end{array}$ \\
\hline $\mathrm{LSD}_{05}$ & 0.167 & 0.096 & 0.1637 & 1.273 \\
\hline \multicolumn{5}{|c|}{$20-30 \mathrm{~cm}$ layer } \\
\hline DP & 6.32 & 9.937 & 1.070 & 9.276 \\
\hline SP & $\begin{array}{l}6.44 \\
6.34\end{array}$ & $\begin{array}{l}8.357^{*} \\
7.903 *\end{array}$ & 0.974 & $\begin{array}{l}8.651 \\
8047\end{array}$ \\
\hline $\mathrm{PT}+\mathrm{aLS}$ & $6.74 *$ & $7.530 *$ & 1.201 & $6.251^{*}$ \\
\hline $\begin{array}{l}\mathrm{PT}+\mathrm{GM} \\
\mathrm{NT}+\mathrm{WM}\end{array}$ & $6.66^{*} *$ & $6.820^{*}$ & 0.949 & $\begin{array}{l}7.248^{*} \\
8566^{*}\end{array}$ \\
\hline $\operatorname{LSD}_{05}$ & 0.252 & 0.205 & 0.2378 & 1.456 \\
\hline
\end{tabular}

Note. DP - deep ploughing (control); SP - shallow ploughing; PT - ploughless tillage; PT + aLS - ploughless tillage and aftereffect of lime sludge; PT + GM - ploughless tillage with green manure; $\mathrm{NT}+\mathrm{WM}$ - no-tillage with winter mulch; the significance of the differences between the treatments was evaluated using the LSD;

* - significant at $P \leq 0.05$ probability level.

long-term application of less intensive tillage (Merbach, Schulz, 2013; Šimon et al., 2015). No significant differences were found in SOC content after the $1^{\text {st }}$ and $2^{\text {nd }}$ crop rotations of our experiment (Liaudanskiene et al., 2018), whereas the inter-annual variability of SOC is known to be high, and the measurement of small changes of SOC content was relatively difficult. Average values of SOC content in the soil samples from different layers are presented in Table 1. The increased SOC content was established in all treatments of reduced tillage compared to DP (control) in $0-10 \mathrm{~cm}$ soil layer. However, significantly higher SOC content was determined under ploughless tillage (PT) as well as in PT and aftereffect of lime sludge $(\mathrm{PT}+\mathrm{aLS})$ and $\mathrm{PT}$ with green manure $(\mathrm{PT}$ + GM) treatments. This effect of green manure can be explained by the high amount of plant residues on the soil surface and the fact that organic carbon from plant biomass inserted in the autumn was more accumulated in the soil compared to the biomass of winter mulch, as found by Romanovskaja et al. (2013). SOC concentration decreased with depth in all tillage treatments. However, in the deeper soil layers SOC concentrations were higher under DP - the decrease of SOC in DP treatment was lower $(3.75 \%)$ than in reduced tillage treatments (from $11 \%$ to $24 \%$ ) in $10-20 \mathrm{~cm}$ layer. A positive effect of reduced tillage on SOC accumulation in the upper soil layers due to low soil disturbance and slow decomposition of surface-placed plant residues has been established in a number of experiments carried out in temperate climate conditions (Šimon et al., 2009; Pospišilova et al., 2010; Villamil et al., 2015; Habova et al., 2019). However, several studies (Dolan et al., 2006; Blanco-Canqui, Lal, 2008) have shown that tillage has an insignificant effect on SOC content, though can change the distribution of SOC in soil profile.

Total nitrogen $\left(\mathrm{N}_{\text {tot }}\right)$ is an important component of SOM that influences decomposition and humification processes in the soil. As shown in Table 1, the tillage effect on the $\mathrm{N}_{\text {tot }}$ content was less pronounced in comparison to 
SOC, and no significant differences were found. However, $\mathrm{N}_{\text {tot }}$ concentrations in the soil were higher under PT and its combinations $\mathrm{PT}+\mathrm{aLS}$ and $\mathrm{PT}+\mathrm{GM}$ as well as under NT + WM compared to DP in the upper $(0-10 \mathrm{~cm})$ soil layer. Following the SOC trend, there is a noticeable decline in $\mathrm{N}_{\text {tot }}$ concentration with soil depth - the decrease under DP was $2.9 \%$, whereas under reduced tillage systems it was from $12 \%$ to $22 \%$ in $10-20 \mathrm{~cm}$ compared to $0-10$ $\mathrm{cm}$ layer. These results are consistent with the findings of Šimon et al. (2009) and Villamil et al. (2015).

Soil carbon-to-nitrogen ratio $(\mathrm{C}: \mathrm{N})$ determines the decomposability of SOM and, therefore, has an impact on $\mathrm{N}$ availability for plant nutrition. The $\mathrm{C}: \mathrm{N}$ tended to decline with depth, and this is in accordance with results of Blanco-Canqui and Lal (2008) and Lou et al. (2012). This could be determined by the increase in the content of clay particles with depth, because higher clay content is often associated with more decomposable SOM with lower C:N (Lou et al., 2012).
Whereas sustainable soil tillage systems reduce soil disturbance and increase the content of plant residues in the upper $(0-10 \mathrm{~cm})$ soil layer, the amount of SOC and $\mathrm{N}_{\text {tot }}$ is also increased; however, soil quality may decline. One of the methods to assess soil quality is the determination of fractional and group composition of humus, which represent approximately $60 \%$ of SOM and have multiplier effect on soil properties. The data presented in Table 2 shows that the SOC of mobile humic (HA1) and fulvic (FA1) acids depended on the tillage applied and on the soil layer. HA1 that are free or weekly bound to non-silicate sesquioxides are not soluble under acidic $(\mathrm{pH}<2)$ conditions but soluble in solution of higher $\mathrm{pH}$ values. The HA1 content ranged from 0.964 to $1.128 \mathrm{mg} \mathrm{kg}^{-1}$ in the upper soil layer, and significant increase in HA1 was obtained under all reduced tillage systems applied compared to DP (control) treatment, except for the treatment with lime sludge $(\mathrm{PT}+\mathrm{aLS})$.

Table 2. Content of mobile (HA1 and FA1) and calcium-bound (HA2 and FA2) humic and fulvic acids in different soil layers (2016-2018)

\begin{tabular}{|c|c|c|c|c|c|c|c|c|c|c|}
\hline Tillage & HA1 & HA2 & FA1a & FA1 & FA2 & HA1 & HA2 & FA1a & FA1 & FA2 \\
\hline system & \multicolumn{5}{|c|}{$\mathrm{g} \mathrm{C} \mathrm{kg}^{-1}$ soil } & \multicolumn{5}{|c|}{$\%$ of SOC } \\
\hline \multicolumn{11}{|c|}{$0-10 \mathrm{~cm}$ layer } \\
\hline DP & 0.964 & .727 & 0.593 & 1.239 & 1.176 & 6.832 & 12.24 & 4.203 & 8.781 & 8.334 \\
\hline SP & $1.128 *$ & 1.828 & 0.612 & $1.159 *$ & $0.962 *$ & 7.663 & 12.42 & 4.158 & 7.873 & 6.535 \\
\hline & $1.056 *$ & $1.877^{*}$ & 0.619 & $1.120 *$ & $1.047 *$ & 6.998 & 12.44 & 4.102 & 7.422 & 6.938 \\
\hline $\begin{array}{l}\mathrm{PT}+\mathrm{aLS} \\
\mathrm{PT}+\mathrm{GM}\end{array}$ & $0.906 *$ & $2.361 *$ & 0.604 & $0.906 *$ & $1.275 *$ & 5.818 & 15.16 & 3.878 & 5.818 & 8.187 \\
\hline $\mathrm{NT}+\mathrm{WM}$ & $1.113 *$ & $1.594 *$ & $\begin{array}{l}0.622 \\
0.663 * \\
\end{array}$ & 1.288 & 1.238 & 7.722 & 1.06 & $\begin{array}{l}4.102 \\
4.600 \\
\end{array}$ & $\begin{array}{l}7.304 \\
8.936 \\
\end{array}$ & 8.589 \\
\hline $\mathrm{LSD}_{05}$ & 0.052 & 0.119 & 0.033 & 0.053 & 0.064 & & & & & \\
\hline \multicolumn{11}{|c|}{$10-20 \mathrm{~cm}$ layer } \\
\hline DP & 0.993 & 1.609 & 0.564 & 0.992 & 0.909 & 7.311 & 11.84 & 4.152 & 7.303 & 6.692 \\
\hline SP & 0.950 & $1.808 *$ & $0.637 *$ & $0.804 *$ & $1.062 *$ & 7.287 & 13.87 & 4.886 & 6.167 & 8.146 \\
\hline & $0.694 *$ & $1.825^{*}$ & 0.566 & $0.779 *$ & $1.035 *$ & 5.664 & 14.89 & 4.619 & 6.358 & 8.447 \\
\hline $\mathrm{PT}+\mathrm{aLS}$ & $0.513 *$ & $2.018 *$ & $0.503 *$ & $0.542 *$ & 0.909 & 4.267 & 16.78 & 4.184 & 4.508 & 7.560 \\
\hline $\mathrm{PT}+\mathrm{GM}$ & $0.627 *$ & $1.825^{*}$ & 0.596 & $0.617 *$ & $1.208 *$ & 5.446 & 15.84 & 5.174 & 5.356 & 10.48 \\
\hline $\mathrm{NT}+\mathrm{WM}$ & $0.672 *$ & $1.794 *$ & $0.627 *$ & $0.671 *$ & $1.003^{*}$ & 5.770 & 15.40 & 5.383 & 5.761 & 8.612 \\
\hline $\mathrm{LSD}_{05}$ & 0.065 & 0.128 & 0.043 & 0.065 & 0.073 & & & & & \\
\hline \multicolumn{11}{|c|}{$20-30 \mathrm{~cm}$ layer } \\
\hline DP & 0.396 & .508 & 0.528 & 0.539 & 1.067 & 3.985 & 15.17 & 5.313 & 5.424 & 10.74 \\
\hline SP & $0.219 *$ & .383 & 0.530 & $0.288 *$ & 1.256 & 2.621 & 16.55 & 6.342 & 3.446 & 15.03 \\
\hline PT & $0.242 *$ & 1.503 & 0.515 & $0.326^{*}$ & 0.851 & 3.062 & 19.02 & 6.516 & 4.125 & 10.77 \\
\hline PT + aLS & $0.215^{*}$ & $1.233 *$ & $0.462 *$ & $0.218^{*}$ & 0.850 & 2.855 & 16.37 & 6.135 & 2.895 & 11.29 \\
\hline $\begin{array}{l}\mathrm{P}+\mathrm{GM} \\
\mathrm{NT}+\mathrm{WM}\end{array}$ & $0.251^{*}$ & $\begin{array}{c}0.903^{*} \\
1.403\end{array}$ & $\begin{array}{l}0.478 \\
0.502\end{array}$ & $\begin{array}{l}0.290^{*} \\
0.296^{*}\end{array}$ & $\begin{array}{l}1.001 \\
0.904\end{array}$ & $\begin{array}{l}3.343 \\
3.162\end{array}$ & $\begin{array}{l}13.24 \\
17.67\end{array}$ & $\begin{array}{l}7.009 \\
6325\end{array}$ & $\begin{array}{l}4.252 \\
3.729\end{array}$ & $\begin{array}{l}14.68 \\
1139\end{array}$ \\
\hline $\mathrm{LSD}_{05}$ & 0.072 & 0.316 & 0.065 & 0.094 & 0.228 & & & & & \\
\hline
\end{tabular}

Explanations under Table 1; FA1a - the most aggressive FA fraction; SOC - soil organic carbon

The reduced tillage intensity and the use of improvers increased the amount of plant residues on the soil surface. This led to changes in the SOM transformation processes generally and humification of SOM specifically. As proposed by Segnini et al. (2013), the plant residues on the soil surface or in the topsoil under less-intensive tillage would be only partially decomposed, resulting in the formation of less humified organic matter, and promotes an increase of labile forms of HS in the topsoil. After liming, the main soil chemical conditions (acidity and content of mobile forms of elements) change (Litvinovich et al., 2017), and the re-grouping in the composition of HS, where part of mobile acids replenishes Ca-bound fraction, is observed (Jokubauskaite et al., 2016). These findings confirm the data of our experiment - under PT + aLS treatment, the lowest HA1 levels were found in all soil layers: $0.906,0.513$ and $0.215 \mathrm{~g} \mathrm{~kg}^{-1}$, respectively, and the highest statistically significant amounts of HA2, 2.361 and $2.018 \mathrm{~g} \mathrm{~kg}^{-1}$, were found in $0-10$ and $10-20 \mathrm{~cm}$ soil layers, respectively.

Although it is stated that from an ecological point of view the mobile fractions of HS are a source of nutrients and energy (Filcheva et al., 2018), the mobile FA are considered agronomically less valuable. In contrast to HA1, the opposite effect of reduced tillage on
FA1 content was evident - the highest amounts of these compounds were found under DP in all soil layers, except for an unsubstantial increase in FA1 in 0-10 cm layer. FA are soluble at all $\mathrm{pH}$ values, have a higher acidity than $\mathrm{HA}$ and act destructively on soil clay minerals, particularly the most aggressive FA1a fraction. The amounts of FA1a fraction differed little between DP and reduced tillage systems in $0-10 \mathrm{~cm}$ soil layer, but a significantly higher content of these acids $\left(0.663 \mathrm{~g} \mathrm{~kg}^{-1}\right)$ was established under $\mathrm{NT}+\mathrm{WM}$ treatment. The relatively high content (from $5.31 \%$ to $7.01 \%$ of SOC) of FA1a fraction in $20-30 \mathrm{~cm}$ layer can be explained by its solubility under a whole range of $\mathrm{pH}$ and high migration potential to the lower parts of the soil profile (Pigareva et al., 2008), whereas in 0$10 \mathrm{~cm}$ layer the FAla proportion in SOC was from $3.87 \%$ to $4.6 \%$, and in $10-20 \mathrm{~cm}$ layer - from $4.15 \%$ to $5.38 \%$. The proportion of HA1 in SOC increased in the upper $(0-10 \mathrm{~cm})$ soil layer, except PT + aLS treatment, and the proportion of FA1 in SOC decreased in comparison to DP (control) treatment, indicating that long-term application of reduced tillage improves the composition of humic substances, as reported by Tobiašova et al. (2018).

HA2 and FA2 fractions are associated with $\mathrm{Ca}$ and are the most agronomically valuable of humus fractions. It was found that HA2 levels increased under 
reduced tillage in $0-10 \mathrm{~cm}$ soil layer, except for NT + WM treatment, where a significantly lower level of HA2 (1.594 $\mathrm{g} \mathrm{kg}^{-1}$ ) was found compared to the DP (control) treatment. This could be explained by the fact that during decomposition of the aboveground biomass for mulch higher amounts of mobile, relatively low molecular weight compounds, especially FA, are formed. The insertion of a large amount of organic matter as green manure (PT + $\mathrm{GM}$ ) does not increase $\mathrm{SOC}$ in $\mathrm{Ca}$-bound HA2 fraction in $0-10 \mathrm{~cm}$ soil layer. This measure may even reduce the proportion of HA2 fraction as found by Arlauskiene et al. (2015) in a study on the use of different swards for green manure, whereas insertion of fresh biomass activates the microbiota and may thus induce degradation of previously stabilized organic matter. The application of lime sludge four times during the $1^{\text {st }}$ and $2^{\text {nd }}$ crop rotations (last incorporated in 2014) increased the concentration of Ca cations $\left(\mathrm{Ca}^{2+}\right)$ in the soil and allowed stabilization of HA and FA by cation bridging mechanism. Compared with DP, the HA2 content under PT + aLS treatment in $0-10 \mathrm{~cm}$ layer was $36.7 \%$ higher, and the FA2 content was only $8.5 \%$ higher. These results are consistent with Litvinovich et al. (2017), who argued that Ca applied with lime materials interacts more actively with HA compared to FA and forms more resistant compounds.

Clay soils have greater SOC accumulation potential - according to Laganiere et al. (2010), soils with high $(>33 \%)$ clay content accumulate approximately $25 \%$ more $\mathrm{C}$ than coarse-textured soils, whereas clay minerals adsorb HS on the surface of particles and catalyse abiotic polymerization of adsorbed HS. Therefore, the adsorbed humic compounds are sequestered by clay minerals and thus form stable organo-mineral complexes. Some studies (Pigareva et al., 2008; Lapa et al., 2011; Guimarães etal., 2013; Burdukovskii et al., 2020) have shown that the amount of $\mathrm{C}$ associated with clay particles largely depends on the soil texture and not on the input of organic residues to the soil.

The results of our experiment demonstrate that the content of clay minerals-bound HA (HA3) was higher in all tillage systems applied compared to DP (control) treatment in $0-10 \mathrm{~cm}$ soil layer (Table 3 ), whereas the influence of tillage intensity on clay minerals-bound FA (FA3) content could not be determined. However, higher levels of HA3 and FA3 were found in PT + aLS treatment: 2.562 and $2.561 \mathrm{~g} \mathrm{~kg}^{-1}$, respectively; for HA3 the increase compared with DP $\left(2.388 \mathrm{~g} \mathrm{~kg}^{-1}\right)$ was significant. As found by Litvinovich et al. (2017) and Barreto et al. (2019), sorption of humic compounds by soil clay minerals is increasing in the presence of $\mathrm{Ca}$. This is consistent with our results and suggests that $\mathrm{Ca}$ should be an important factor for SOC sequestration in a clay loam. Meanwhile, the lowest amounts of HS stabilized by clay minerals were found in the PT $+\mathrm{GM}$ and NT $+\mathrm{WM}$ treatments, which contained more mobile HS formed from plant residues. When comparing the proportions of HA 3 and FA3 in the humus composition ( $\%$ of SOC), it was found that FA3 content was higher than that of HA3 in all soil layers studied. Pinskiy et al. (2014) found that at the beginning clay particles adsorb more strongly FA as they are more chemically active with higher content of functional groups. The HA3 and FA3 fractions accounted for a substantial part of the total HA and FA in a clay loam: $44-47.4 \%$ and $43-48 \%$, respectively.

Humin refers to that component of the SOM, which is insoluble in aqueous base at any $\mathrm{pH}$ and is a heterogeneous mixture of old and new macro-organic substances. Humin is the most resistant to decomposition of all HS. However, there is a lack knowledge about humin properties and importance for soil quality. As stated by Litvinovich et al. (2017) and Han et al. (2019), humin generally represents the highest proportion of soil humus composition. The results of our experiment in a clay loam showed that the humin fraction represented from $22 \%$ to $29 \%$ of SOC in different soil layers and accounted for most of the soil humus in all treatments; however, it showed no clear trend of distribution in different soil layers.

The increase in SOC content because of the reduction in tillage intensity is accompanied by an increase in the amount of HA. The relative proportion of HA to total SOC, understood as the humification degree (HD), shows the resistance of SOM. The increase of HD is valuable both agronomically and ecologically. The data in Table 4 shows that HD in the DP (control) treatment decreased with increasing depth from $36 \%$ in $0-10 \mathrm{~cm}$ layer to $33 \%$ in $20-30 \mathrm{~cm}$ layer. The reduction of tillage intensity allowed SOC to accumulate in fractions resistant to degradation: the HD increased in $10-20 \mathrm{~cm}$ layer for all reduced tillage systems compared to 0

Table 3. Content of clay minerals-bound (HA3 and FA3) humic and fulvic acids and humin in different soil layers (2016-2018)

\begin{tabular}{|c|c|c|c|c|c|c|}
\hline \multirow{2}{*}{ Tillage system } & HA3 & FA3 & Humin & HA3 & FA3 & Humin \\
\hline & \multicolumn{3}{|c|}{$\mathrm{g} \mathrm{C} \mathrm{kg}^{-1}$ soil } & \multicolumn{3}{|c|}{$\%$ of SOC } \\
\hline \multicolumn{7}{|c|}{$0-10 \mathrm{~cm}$ layer } \\
\hline DP & 2.388 & 2.469 & 3.349 & 16.92 & 17.50 & 23.73 \\
\hline SP & 2.454 & 2.494 & 3.680 & 16.67 & 16.94 & 25.00 \\
\hline & 2.444 & 2.461 & $4.266^{*}$ & 16.20 & 6.31 & 28.27 \\
\hline $\mathrm{PT}+\mathrm{aLS}$ & $2.562 *$ & 2.561 & $4.202 *$ & 16.45 & 16.53 & 26.98 \\
\hline $\mathrm{PT}+\mathrm{GM}$ & 2.434 & 2.442 & $4.205 *$ & 16.05 & 16.10 & 27.73 \\
\hline $\mathrm{NT}+\mathrm{WM}$ & 2.429 & 2.440 & 3.454 & 16.85 & 16.93 & 23.96 \\
\hline \multirow[t]{2}{*}{$\mathrm{LSD}_{05}$} & 0.135 & 0.142 & 0.384 & & & \\
\hline & \multicolumn{6}{|c|}{$10-20 \mathrm{~cm}$ layer } \\
\hline$\overline{\mathrm{DP}}$ & 2.236 & 2.402 & 3.369 & 6.46 & 17.68 & 24.80 \\
\hline $\mathrm{SP}$ & 2.268 & 2.368 & 2.935 & 17.40 & 18.16 & 22.51 \\
\hline PT & $1.985^{*}$ & 2.231 & 2.983 & 16.20 & 18.21 & 24.34 \\
\hline $\mathrm{PT}+\mathrm{aLS}$ & $2.067 *$ & $2.002 *$ & 3.249 & 17.19 & 16.65 & 27.02 \\
\hline $\begin{array}{l}\mathrm{PT}+\mathrm{GM} \\
\mathrm{NT}+\mathrm{WM}\end{array}$ & $\begin{array}{l}1.744^{*} \\
1.761 *\end{array}$ & $\begin{array}{l}1.766^{*} \\
1.926^{*}\end{array}$ & $\begin{array}{l}2.948 \\
2.979\end{array}$ & 15.14 & 15.33 & 25.60 \\
\hline \multirow[t]{2}{*}{$\mathrm{LSD}_{05}$} & 0.154 & 0.174 & 0.435 & & & \\
\hline & \multicolumn{6}{|c|}{$20-30 \mathrm{~cm}$ layer } \\
\hline DP & 1.386 & 1.794 & 2.422 & 13.95 & 18.05 & 24.37 \\
\hline SP & 1.233 & $1.326 *$ & 1.947 & 14.75 & 15.87 & 23.30 \\
\hline PT + aLS & $1.145^{*}$ & $\begin{array}{l}.251 * \\
.120 *\end{array}$ & $\begin{array}{l}1.892 \\
2.173\end{array}$ & $\begin{array}{l}14.49 \\
14.75\end{array}$ & 15.83 & $\begin{array}{l}23.94 \\
28.86\end{array}$ \\
\hline $\mathrm{PT}+\mathrm{GM}$ & $1.068 *$ & $1.119 *$ & 1.950 & 15.66 & 16.42 & 28.59 \\
\hline $\mathrm{NT}+\mathrm{WM}$ & $1.174 *$ & $1.300 *$ & 1.911 & 14.79 & 16.38 & 24.08 \\
\hline $\mathrm{LSD}_{05}$ & 0.189 & 0.197 & 0.534 & & & \\
\hline
\end{tabular}

Explanations under Table 1; SOC - soil organic carbon 
Table 4. Qualitative characteristics of organic matter in different soil layers (2016-2018)

\begin{tabular}{|c|c|c|c|c|c|c|}
\hline Tillage system & $\mathrm{HD} \%$ & HA:FA & HA1:FA1 & HA2:FA2 & Aggressiveness & Mobility \\
\hline \multicolumn{7}{|c|}{$0-10 \mathrm{~cm}$ layer } \\
\hline$\overline{\mathrm{DP}}$ & 36.00 & 0.927 & 0.778 & 1.468 & 5.618 & 0.963 \\
\hline SP & 37.43 & 1.034 & 0.973 & 1.900 & 5.647 & 1.039 \\
\hline PT & 35.63 & 1.025 & 0.943 & 1.793 & 5.826 & 0.956 \\
\hline $\mathrm{PT}+\mathrm{aLS}$ & 37.43 & 1.088 & 1.000 & 1.852 & 5.399 & 0.664 \\
\hline $\mathrm{PT}+\mathrm{GM}$ & 34.72 & $\begin{array}{l}1.080 \\
0.960\end{array}$ & 0.926 & 1.386 & 5.785 & 0.930 \\
\hline NT + WM & 35.63 & 0.912 & 0.864 & $\begin{array}{l}1.280 \\
1.288\end{array}$ & 6.159 & 1.082 \\
\hline \multicolumn{7}{|c|}{$10-20 \mathrm{~cm}$ layer } \\
\hline$\overline{D P}$ & 35.62 & 0.994 & 1.001 & 1.770 & 5.811 & 1.012 \\
\hline SP & 38.55 & 1.032 & 1.182 & 1.702 & 6.436 & 0.833 \\
\hline PT & 36.27 & 0.964 & 0.891 & 1.763 & 6.251 & 0.713 \\
\hline $\mathrm{PT}+\mathrm{aLS}$ & 38.24 & 1.162 & 0.946 & 2.220 & 5.708 & 0.532 \\
\hline $\mathrm{PT}+\mathrm{GM}$ & 36.16 & 0.995 & 1.016 & 1.511 & 7.135 & 0.617 \\
\hline $\mathrm{NT}+\mathrm{WM}$ & 36.29 & 1.000 & 1.001 & 1.789 & 7.417 & 0.704 \\
\hline \multicolumn{7}{|c|}{$20-30 \mathrm{~cm}$ layer } \\
\hline$\overline{D P}$ & 33.11 & 0.838 & 0.735 & 1.413 & 7.315 & 0.568 \\
\hline SP & 33.92 & 0.834 & 0.760 & 1.101 & 8.500 & 0.393 \\
\hline PT & 36.57 & 0.982 & 0.742 & 1.766 & 8.829 & 0.460 \\
\hline $\mathrm{PT}+\mathrm{aLS}$ & 33.98 & 0.966 & 0.986 & 1.450 & 8.871 & 0.430 \\
\hline $\mathrm{PT}+\mathrm{GM}$ & 32.24 & 0.761 & 0.786 & 0.902 & 9.395 & 0.523 \\
\hline $\mathrm{NT}+\mathrm{WM}$ & 35.63 & 0.942 & 0.848 & 1.552 & 8.611 & 0.455 \\
\hline
\end{tabular}

Explanations under Table 1; HD - humification degree; acid ratios: HA:FA - humic-to-fulvic, HA1:FA1 - mobile humic-to-fulvic, HA2:FA2 - Ca-bound humic-to-fulvic

$10 \mathrm{~cm}$ layer. This may be related to the more favourable mineralization conditions in the topsoil, resulting in higher levels of mobile substances (Segnini et al., 2013) and more favourable humification conditions in 10-20 cm layer. The increase of HD means that SOC is preserved in more recalcitrant form. According to Lobanov et al. (2015) and Radmanović et al. (2015), the HD depends on soil conditions with soil $\mathrm{pH}$ being one of the decisive factors - the higher soil $\mathrm{pH}$ and $\mathrm{HD}$, and the results of our experiment partially support this statement.

The relationships between different fractions of HS can help assess the effect of tillage on soil quality. The humic-to-fulvic acids ratio (HA:FA) is known as an index of humus type and an indicator of the polymerization and condensation of SOM and shows potential mobility of organic C in the soil (Orlov et al., 2004; Guimarães et al., 2013; Ovchinnikova, 2018). The HA:FA close to 1 indicates a good quality of SOM, and when this ratio is greater than 1, this points out that the mobile and labile fractions are lost. In our experiment, the HA:FA varied from 0.912 to 1.088 (in $0-10 \mathrm{~cm}$ layer), from 0.964 to 1.162 (in 10-20 cm layer) and from 0.761 to 0.982 (in 20 $30 \mathrm{~cm}$ layer). Except PT treatment, the highest HA:FA was found in 10-20 cm layer, which suggests that, according to Orlov et al. (2004), favourable conditions for the activity of microorganisms probably promotes the formation of condensed alkali-soluble HS (i.e. HA) with greater stability in this layer, and the soil matrix accumulates the most insoluble HS (Dorado et al., 2016). The amount of HA increased and the amount of FA decreased in the soil under PT + aLS treatment, which resulted in a wider HA:FA, and this is consistent with Lapa et al. (2011).

The ratios of the first and second HA fractions to the corresponding FA fractions were calculated to estimate the rate (or intensity) of humification. The mobile humic-to-fulvic acids ratio (HA1:FA1) was used to assess the formation rate of new HA and their mobile forms (Ovchinnikova, 2009). It can be seen from the data in Table 4 that HA1:FA1, which indicated the major direction of the first humification stage, was from 0.864 to 1 under reduced tillage and combinations of reduced tillage with soil improvement practices in $0-10 \mathrm{~cm}$ soil layer, while under the DP (control) treatment this ratio was as low as 0.778 . Therefore, it can be stated that the investigated measures favoured the formation of new HA, especially their mobile forms. However, lime sludge, which was inserted up to $12 \mathrm{~cm}$ for the last time in 2014 , resulted in a reduction of both HA1 and FA1 in 10-20 cm layer (Table 2), so a lower HA1:FA1 was found here.
For the Ca-bound humic-to-fulvic acids ratio (HA2:FA2), which characterized the intensity of the second humification stage and was used to assess the degree of polymerization rate of HS and the formation of humates (Ovchinnikova, 2009), a slight decrease was found under $\mathrm{PT}+\mathrm{GM}$ and NT + WM treatments in $0-10 \mathrm{~cm}$ layer, and an appreciable increase under PT + aLS treatment in 10-20 cm layer compared to the DP. This can be explained by the fact that the plant residues increased and intensified the activity of microorganisms and favoured the synthesis of newly formed labile HS, and some part of mobile HS migrated down the profile and bound with $\mathrm{Ca}^{+2}$ and thus transformed into Ca humates.

The aggressiveness of FAs was characterized by the relative proportion of the most aggressive FAla fraction. The obvious influence of tillage systems on this indicator was found in $0-10$ and $10-20 \mathrm{~cm}$ soil layers. The increased amount of plant residues under NT + WM treatment intensified soil microbiological activity, resulting in the formation of new mobile HS, particularly the most aggressive FAla. As documented by Romanovskaja et al. (2013), more HS are accumulated when the plant mass is added to the soil in the autumn (PT + GM) compared to springtime insertion. Lime sludge applied in previous crop rotations $(\mathrm{PT}+\mathrm{aLS})$ reduced this index of humus due to the interaction of $\mathrm{HS}$ with $\mathrm{Ca}^{+2}$.

In order to evaluate the qualitative changes in humus as influenced by the tillage systems applied, the mobility of HS was evaluated. In the upper $(0-10 \mathrm{~cm})$ soil layer, the mobility of HS increased under SP and NT + WM treatments compared to DP treatment by $7.9 \%$ and $12.4 \%$, respectively; under PT and PT + GM treatments the mobility of HS decreased slightly; however, PT + aLS application reduced HS mobility by $31 \%$. In the lower soil layers, HS mobility decreased due to reduced tillage: the effect of PT + aLS was the strongest with HS mobility decreasing by $47.4 \%$ and $24.3 \%$ in $10-20$ and 20-30 cm layers, respectively. In a clay loam, HS are less mobile and due to a high content of clay particles are more bound with clay particles, which determines the stabilization of organic compounds.

\section{Conclusions}

The present study was designed to determine the effect of reduced tillage and the combinations of reduced tillage with soil improvement practices on soil organic carbon (SOC) and the quantity and quality of humus in 
a clay loam. One of the more unexpected findings of this research is that the reduced tillage systems applied over 12 years did not restore SOC and only inhibited its further decomposition.

1. The reduction in tillage intensity led to an increase in the amount of SOC only in the upper $(0-10$ $\mathrm{cm})$ soil layer. The addition of organic matter of green manure $(\mathrm{PT}+\mathrm{GM})$ and winter mulch $(\mathrm{NT}+\mathrm{WM})$ promoted microbiological activity and mineralization of the soil organic matter (SOM), already present in the soil, so SOC and total nitrogen $\left(\mathrm{N}_{\text {tot }}\right)$ levels in the soil did not increase in proportion to the amount of fresh organic matter added.

2. The reduced tillage and the use of soil improvers had influence on the changes in the fractional composition of soil humus. The increased content of plant residues under PT + GM and NT + WM treatments resulted in higher amounts of mobile humic substances (HS) in the upper soil layer, while the lime sludge $(\mathrm{PT}+\mathrm{aLS})$, last incorporated in 2014, increased the amount of agronomically most valuable Ca-bound HS. Also, higher amounts of clay minerals-bound and ecologically relevant HS were found under PT + aLS treatment - calcium should be an important factor in SOC sequestration in a clay loam.

3 . The humification degree increased in $0-30 \mathrm{~cm}$ soil layer under all investigated tillage systems compared to conventional tillage. The use of soil improvers had a more significant effect than just reduction of tillage. However, due to the complexity of SOM a clear relationship between SOM qualitative characteristics and tillage systems applied was not identified.

\section{Acknowledgments}

The experimental findings were obtained through the research programme "Productivity and sustainability of agricultural and forest soils" implemented by Lithuanian Research Centre for Agriculture and Forestry.

The authors thank the reviewers and the editors for their careful reading and very helpful and constructive comments.

Received 14042020

Accepted 22092020

\section{References}

Arlauskiene A., Slepetiene A., Liaudanskiene I., Sarunaite L., Amaleviciute K., Velykis A. 2015. The influence of shortlived legume swards and straw on soil humic substances in a clay loam Cambisol. Fresenius Environmental Bulletin, 24 (5): $1636-1640$.

Barreto M., Ramlogan M., Rouff A., Elzinga E., Alleoni L. R. F 2019. Calcium improves humic acid adsorption by soil minerals. Proceedings of $19^{\text {th }}$ international conference Humic Substances and their Contribution to the Climate Change Mitigation, p. 253-254.

Blanco-Canqui H., Lal R. 2008. No-tillage and soil-profile carbon sequestration: an on-farm assessment. Soil Science Soriety of America Iournal 72: 693-701. https://doi.org/10.2136/sssaj2007.0233

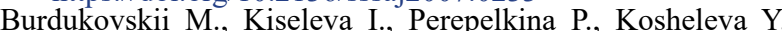
2020. Impact of different fallow durations on soil aggregate structure and humus status parameters. Soil and Water Research 15(1): 1-8 https://doi.org/10.17221/174/2018-SWR

Dolan M̄. S., Cíapp C. E. Ailimaras $\bar{K}$. R., Baker J. M., Molina J. A. E. 2006. Soil organic carbon and nitrogen in a Minnesota soil as related to tillage, residue and nitrogen management. Soil and Tillage Research, 89: 221-231. https://doi.org/10.1016/j.still.2005.07.015

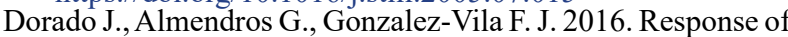
humic acid structure to soil tillage management as revealed by analytical pyrolysis. Journal of Analytical and Applied Pyrolysis 117:56-63.

https://doi.org/10.1016/j.jaap.2015.12.016
FAO. 2017. Soil organic carbon: the hidden potential. Food and Agriculture Organization of the United Nations. http://www.fao.org/3/a-i6937e.pdf\%20

Filcheva E., Hrisova M., Nikolova P., Popova T., Chakalov K., Savov V. 2018. Quantitative and qualitative characterisation of humic products with spectral parameters. Journal of Soils and Sediments $18: 2863-2867$ https://doi.org/10.1007/s11368-018-2021-4

Guimarães D. V., Gonzaga M. I. S., da Silva T. O., da Silva T. L., da Silva Dias N., Silva Matias M. I. 2013. Soil organic matter pools and carbon fractions in soil under different land uses. Soil and Tillage Research 126: 177-182. https://doi.org/10.1016/j.still.2012.07.010

Habova M., Pospišilova L., Hlavinka P., Trnka M., Barančikova G., Tarasovičova Z., Takač J., Koco Š., Menšik L., Nerušil P. 2019. Carbon pool in soil under organic and conventional farming systems. Soil and Water Research, 14 (3): 145-152. https://doi.org/10.17221/71/2018-SWR

Han B., Kitamura K., Hirota M., Shen H., Tang Y., Suzuki T., Fujitake N. 2019. Humus composition and humification degree of humic acids of alpine meadow soils in the northeasten part of the Qinghai-Tibet Plateau. Soil Science and Plant Nutrition. 65 (1):11-19. https://doi.org/10.1080/00380768.2018.1547098

Jokubauskaite I., Karčauskienè D., Slepetiene A., Repsiene R., Amaleviciute K. 2016. Effect of different fertilization modes on soil organic carbon sequestration in acid soils. Acta Agriculturae Scandinavica, Section B: Soil and Plant Science $66(8): 647-652$ https://doi.org/10.1080/09064710.2016.1181200

Keesstra S. D., Bouma J., Wallinga J., Tittonell P., Smith P., Cerdà A., Montanarella L., Quinton J. N., Pachepsky Y., van der Putten W. H., Bardgett R. D., Moolenaar S., Mol G., Jansen B., Fresco L. O. 2016. The significance of soils and soil science towards realization of the United Nations Sustainahle Develonment Goals. Soil. 2: 111-128. https://doi.org/10.5194/soil-2-111-2016

Kemmitt S. J., Wright D., Goulding K. W. T., Jones D. L. 2006. $\mathrm{pH}$ regulation of carbon and nitrogen dynamics in two agricultural soils. Soil Biolnov and Biochemistry. 38: 898-911. https://doi.org/10.1016/j.soilbio.2005.08.006

Laganiere J., Angers D. A., Pare D. 2010. Carbon accumulation in agricultural soils after afforestation: a meta-analysis. Glohal Change Biology. 16: 439-453 https://doi.org/10.1111/j.1365-2486.2009.01930.x

Lapa V. V., Seraya T. M., Bogatyreva E. N., Biryukova O. M. 2011. The effect of long-term fertilizer application on the group and fractional composition of humus in a soddy-podzolic light loamv soil. Furasian Soil Science 44 (1): 100-104. https://doi.org/10.1134/S106422931101008X

Liaudanskiene I., Velykis A., Satkus A., Zukaitis T. 2018. The impact of tillage on soil organic carbon accumulation in clay loam soil in Lithuania. Proceedings of $10^{\text {th }}$ international soil science congress Environment and Soil Resources Conservation, p. 193-196.

Litvinovich A., Pavlova O., Lavrishchev A., Bure V., Saljnikov E. 2017. Empirical models of transformations of humic acids and humin in Umbric Albeluvisol Abruptic as influenced hy liming. 7emdirhvste-Agriculture, 104 (2): 115-122. https://doi.org/10.13080/z-a.2017.104.015

Lobanov V. G., Alexandrova A. V., Shuray K. N., Avdeev A. S., Rashid I. D. 2015. Structural and functional characteristics of humic acid soils of Krasnodar Region. КубГАУ, $109(05)$ : 1-10 (in Russian). http://ej.kubagro.ru/2015/05/pdf/71.pdf

Lou Y., Xu M., Chen X., He X., Zhao K. 2012. Stratification of soil organic $\mathrm{C}, \mathrm{N}$ and $\mathrm{C}: \mathrm{N}$ ratio as affected by conservation tillage in two maize fields of China. Catena 95: 124-130. https://doi.org/10.1016/j.catena.2012.02.009

Merbach I., Schulz E. 2013. Long-term fertilization effects on crop yields, soil fertility and sustainability in the Static Fertilization Experiment Bad Lauchstädt under climatic conditions 2001-2010. Archives of Agronomy and Soil Science $59(8)$ : 1041-1057 https://doi.org/10.1080/03650340.2012.702895

Nebbioso A., Vinci G., Drosos M., Soaccini R., Piccolo A. 2015. Unveiling the molecular composition of the unextractable soil organic fraction (humin) by humeomics. Biology and Fertility of Soils. 51:443-45 https://doi.org/10.1007/s00374-014-0991-y 
Nikitin B. A. 1999. Methods for soil humus determination. Agro Chemistry, 3 (2): 156-158 (in Russian).

Ohno T., Hess N. J., Qafoku N. P. 2019. Current understanding of the use of alkaline extractions of soils to investigate soil organic matter and environmental processes. Journal of Fnvironmental Quality, 48: 1561-1564. https://doi.org/10.2134/jeq2019.08.0292

Orlov D. S., Biryukova U. N., Rozanova M. S. 2004. Revised system of the humus status parameters of soils and their genetic horizons. Eurasian Soil Science, 37 (8): 798-805.

Ovchinnikova M. F. 2009. Transformation of humic substances in soddy-podzolic soils under agrogenic impacts. Moscow Iniversity Snil Science Rulletin 64: 10-16 https://doi.org/10.3103/S0147687409010025

Ovchinnikova M. F. 2U18. Changes in the content, composition, and properties of humic substances in particle-size fractions of soddy-podzolic soils under the impact of long-term drainaoe Furacian Soil Science 51 (6): 647-657. https://doi.org/10.1134/S1064229318060121

Pigareva N. N., Korsunova 1. M., P'yankova N. A. 2008 Specific features of the humus status in soils of Buryatia. Eurasian Soil Science 41 (4): 386-393. https://doi.org/10.1134/S1064229308040042

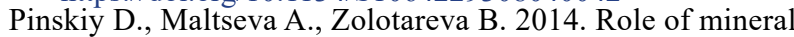
matrix composition and properties in the transformation of corn residues. Furacian Inurnal of Soil Science, 3 (3): 172181. https://doi.org/10.18393/ejss. 86540

Ponomareva V. V., Plotnikova I. A. 1980. Humus and soil formation. Leningrad, 198 p. (in Russian).

Pospišilova L., Fasurova N., Petrašova V. 2010. Humus content and quality under different soil tillage systems. Soil and Water Recearch 5(3). 90-05

https://doi.org/10.17221/20/2009-SWR

Radmanovic S. B., torđevic A. K., Nikolić N. S. 2015. Humification degree of Rendzina soil humic acids influenced by carbonate leaching and land use. Journal of A gricultural Sciences, 60 (4): 443-453. https://doi.org/10.2298/JAS'1504443R

Romanovskaja D., Iripoiskaja L., Slepetienè A. 2013. The effect of green manure of different chemical composition on humus formation in a Haplic Luvisol. Žemès ūkio mokslai 20 (1). 26-33 (in I ithuanian)

https://doi.org/10.6001/zemesukiomokslai.v20i1.2636

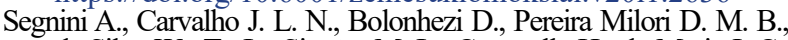
da Silva W. T. L., Simões M. L., Cantarella H., de Maria I. C., Neto L. M. 2013. Carbon stock and humification index of organic matter affected by sugarcane straw and soil management Scientia A gricnla 70 (5): 321-326 https://doi.org/10.1590/S0103-90162013000500006

Silva $\overline{\mathbf{J}}$. $\overline{\mathbf{K}}$., Siliva $\overline{\mathbf{D}}$. $\overline{\mathbf{J}}$., Gava $\overline{\mathrm{C}}$. A. $\overline{\mathbf{I}}$, de Üliveira $\overline{\mathbf{I}}$. C. T. de Freitas M. S. C. 2016. Carbon in humic fractions of organic matter in soil treated with organic composts under mango cultivation Revista Rracileira de Ciência do Soln 40: e0150095. https://doi.org/10.1590/18069657rbcs20150095

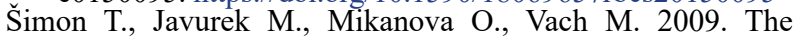
influence of tillage systems on soil organic matter and soil hydronhohicity Soil and Tillage Research, 105: 44-48. https://doi.org/10.1016/j.still.2009.05.004

Šimon $\overline{1}$., Kunzova $\bar{E}$., Friediova $\bar{M}$. $\overline{2} 015$. The effect of digestate, cattle slurry and mineral fertilization on the winter wheat yield and soil quality parameters. Plant, Soil and Environment 61 (11): 522-527. https://doi.org/10.17221/530/2015-PSE

Tobiasova $\bar{E}$., Barancikova Ğ., Gomoryova E., Dęska B., Banach-Szott M. 2018. Humus substances and soil aggregates in the soils with different texture Snil and Water Research, 13 (1): 44-50. https://doi.org/10.17221/31/2017-SWR

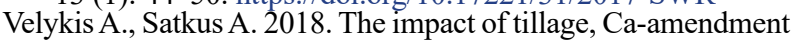
and cover crop on the physical state of a clay loam soil. Zemdirbvste-A oriculture, $105(1): 3-10$. https://doi.org/10.13080/z-a.2018.105.001

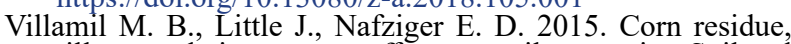
tillage, and nitrogen rate effects on soil properties. Soil and Tillage Research, 151:61-66. https://doi.org/10.1016/j.still.2015.03.005

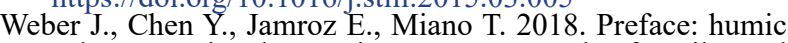
substances in the environment. Journal of Soils and Sedimente, 18. 2665-2667. https://doi.org/10.1007/s11368-018-2052-x

WRB. 2U14. World reference base for soil resources. World Soil Resources Reports No. 106. FAO, 189 p.

\title{
Žemės dirbimo būdụ įtaka humifikuotos organinès anglies pasiskirstymui sunkiame priemolyje
}

\author{
I. Liaudanskienè ${ }^{1}$, T. Žukaitis ${ }^{1}$, A. Velykis ${ }^{2}$, A. Satkus ${ }^{2}$, I. Parašotas ${ }^{1}$
}

${ }^{1}$ Lietuvos agrarinių ir miškų mokslų centro Žemdirbystės institutas

${ }^{2}$ Lietuvos agrarinių ir miškų mokslų centro Joniškèlio bandymų stotis

\section{Santrauka}

Siekiant nustatyti supaprastinto žemės dirbimo ir papildomų priemonių įtaką dirvožemio organinei angliai ir humuso kiekiui bei kokybei sunkiame priemolyje, 2016-2018 m. buvo atliktas tyrimas. Lietuvos agrarinių ir miškų mokslų centro Joniškèlio bandymų stotyje lauko eksperimente tirtos šios žemès dirbimo sistemos: 1) gilus arimas 21-23 cm gyliu (kontrolinis variantas), 2) seklus arimas 15-17 cm gyliu, 3) bearimis žemès dirbimas (10-12 cm gyliu), 4) bearimis žemès dirbimas su liekamuoju kalkių purvo poveikiu, 5) bearimis žemės dirbimas su tarpiniais pasėliais žaliajai trąšai ir 6) tiesioginè sèja su tarpiniais pasėliais mulčiui žiemai. Supaprastintas žemès dirbimas didino organinès anglies ir huminių medžiagų C kiekị dirvožemio viršutiniame $0-10 \mathrm{~cm}$ sluoksnyje. Organinės medžiagos įterpimas žaliosios trąšos ir mulčio pavidalu paskatino dirvožemio mikrobiologinį aktyvumą ir dirvožemyje esančios organinès medžiagos mineralizaciją, todèl organinès anglies ir suminio azoto kiekis dirvožemyje nedidèjo proporcingai ịterptos organinès medžiagos kiekiui. Taikytos žemès dirbimo sistemos turèjo ịtakos humuso frakcinès sudèties pokyčiams. Didesnis augalinių liekanų kiekis bearimio žemès dirbimo su tarpiniais pasèliais žaliajai trąšai ir tiesioginès sèjos su tarpiniais pasėliais mulčiui variantuose lèmé mobiliųjų huminių medžiagų kiekio padidèjimą dirvožemio viršutiniame sluoksnyje, o kalkių purvo įterpimas taikant bearimi žemès dirbimą padidino su kalciu sujungtų agronominiu atžvilgiu vertingiausių humuso medžiagų kiekị. Didžiausi su molio mineralais susijusių ekologiniu atžvilgiu vertingų humuso medžiagų kiekiai nustatyti taikant bearimị žemès dirbimą su kalkių purvo įterpimu, nes kalcis yra svarbus organinès anglies išsaugojimo sunkiame priemolyje veiksnys.

Organinès medžiagos humifikacijos laipsnis dirvožemio 0-30 cm sluoksnyje padidèjo taikant supaprastintą žemės dirbimą, lyginant su tradiciniu žemès dirbimu. Papildomų gerinimo priemonių taikymas turejo didesnę reikšmę nei tik žemès dirbimo supaprastinimas, tačiau dèl dirvožemio organinès medžiagos sudètingumo esminis jos kokybinių rodiklių ir taikyto žemès dirbimo ryšys nebuvo nustatytas.

Reikšminiai žodžiai: dirvožemio organinè anglis, fulvinės rūgštys, huminės rūgštys, humifikacijos laipsnis, huminas. 